BIOTECHNOLOGY TECHNIQUES

Volume 7 No.4 (April 1993) pp.271-276

Received 19th January

\title{
EFFECT OF FIXATION TEMPERATURE ON FLOW CYTOMETRIC MEASUREMENT OF INTRACELLULAR ANTIBODY CONTENT OF HYBRIDOMAS DURING BATCH CULTURE
}

\author{
Gyun Min Lee*, Alice S. Chuck ${ }^{1}$, and Bernhard O. Palsson 1 \\ Department of Biotechnology, Korea Advanced Institute of Science \& Technology, \\ Kuseong-Dong, Yuseong-Gu, Taejun 305-701, Korea \\ and \\ 1 Department of Chemical Engineering, University of Michigan, \\ Herbert H. Dow Building, Ann Arbor, MI 48109
}

\begin{abstract}
In order to investigate the effect of fixation temperature on flow cytometric measurement of intracellular antibody content of hybridoma cells, cells in different growth stages during a batch culture were fixed and stored at 4 and $-20^{\circ} \mathrm{C}$, respectively. Flow cytometric analysis indicates that both fixation temperatures can be used in monitoring the changes in intracellular antibody content of the cells during a batch culture. However, it is better to fix and store the cells at $-20^{\circ} \mathrm{C}$ than $4{ }^{\circ} \mathrm{C}$ with regard to preservation of intracellular antibody and storage stability.
\end{abstract}

\section{INTRODUCTION}

The major advantage of the flow cytometric technique is that specific biochemical and immunological changes in each cell within a population are obtained, rather than an average value of these changes in an entire population as obtained by other techniques.

Flow cytometric techniques have been specifically applied for studying antibody production kinetics in hybridomas (Meilhoc et al., 1989; Dalili and Ollis, 1990; Sen et al., 1990; Al-Rubeai et al., 1991; McKinney et al., 1991) and population dynamics between antibody producer and non-producer populations (Lee and Palsson 1990; Ozturk and Palsson, 1990; Chuck and Palsson, 1992; Chuck et al., 1992) or high and low producer populations (Altshuler et al., 1986; Heath et al., 1990). The changes in surface and intracellular antibody levels of hybridomas during the culture are quantified for this purpose. Quantification of antibodies is made by measuring the fluorescence intensity induced by immunofluorescent labelling of antibodies. Immunofluorescent labelling of surface antibodies does not necessarily require fixing the cells. However, in order to label the intracellular antibodies of hybridomas, the external membrane of the cells should be first permeablized (Shapiro, 1988). A fluorescein isothiocyanate (FITC)-conjugated anti-immunoglobulin can then diffuse into the cells and bind to the intracellular antibody. 
Among many different fixation protocols, ethanol and formaldehyde are widely used in flow cytometry (Shapiro, 1988; Watson, 1991). The fixation process can cause major problems in immunofluorescence staining with reduction or loss of antibody binding due to epitope modulation induced by the fixation (Levitt and King, 1987). Various fixative solutions were found to have different denaturing effects on cell surface antigen of mouse T-lymphocytes (Van Ewijk et al., 1984). Fixation temperature may also influence the degree of denaturation of antibody. The cells are often fixed at either $4{ }^{\circ} \mathrm{C}$ (Clevenger et al., 1985; Levitt and King, 1987; Dalili and Ollis, 1990; Heath et al., 1990) or $-20^{\circ} \mathrm{C}$ (Jacobberger et al., 1986; Chuck and Palsson, 1992; Reddy et al., 1992).

In this study, S3H5/ $/ 2 \mathrm{bA} 2$ hybridomas were fixed at both 4 and $-20^{\circ} \mathrm{C}$ using $70 \%(\mathrm{v} / \mathrm{v})$ ethanol, and the effect of fixation temperature on flow cytometric measurements of intracellular antibody content of the cells during a batch culture was monitored. In addition, we investigated the storage stability of intracellular antibody at these two fixation temperatures.

\section{MATERIALS AND METHODS}

Cell line, medium, and culture maintenance Two murine hybridoma cell lines were used in this study. One cell line was $\mathrm{S} 3 \mathrm{H} 5 / \gamma 2 \mathrm{bA} 2$ provided by Dr. Mark Kaminski from the University of the Michigan Medical Center. The antibody produced by this cell line is $\mathrm{IgG}_{2} \mathrm{~b}$ anti-idiotype antibody, directed against a carcinogen-induced B cell tumor (38C13) (Bergman and Haimovich, 1977). The fusion partner used was P3/x63/Ag8.653. The other cell line used as a negative control was S3H5/NP. This cell line was originally derived from $\mathrm{S} 3 \mathrm{H} 5 / / 2 \mathrm{bA} 2$, and lost its antibody productivity (Lee and Palsson, 1990). The medium for culture maintenance was Iscove's modified Dulbecco's medium (IMDM, Sigma, St.Louis, MO) supplemented with $10 \%(\mathrm{v} / \mathrm{v})$ fetal bovine serum (FBS, Gibco Laboratories, Grand Island, NY). 100 units $/ \mathrm{ml}$ of penicillin, and $100 \mu \mathrm{g} / \mathrm{ml}$ of streptomycin (Sigma). The cells were maintained in $25 \mathrm{~cm}^{2} \mathrm{~T}$ flasks (Bellco Glass, Inc., Vineland, NJ) in a $5 \% \mathrm{CO}_{2}$ /air mixture, humidified at $37^{\circ} \mathrm{C}$. The cells were diluted 1:5 with fresh medium every other day.

Cell cultures Exponentially growing cells were inoculated into three $75 \mathrm{~cm}^{2}$ T-flasks containing $30 \mathrm{ml}$ of IMDM supplemented with $10 \%(\mathrm{v} / \mathrm{v})$ FBS. The initial cell concentration was ca. $10^{5} \mathrm{cell} / \mathrm{s} / \mathrm{ml}$. Since the cell concentration in the early culture was not high enough, $10 \mathrm{ml}$ of cell culture suspension was taken from the flasks to prepare flow cytometric samples. Experiments were repeated three times. All the experiments were performed in a humidified $\mathrm{CO}_{2}$ incubator adjusted to $37^{\circ} \mathrm{C}$.

Quantification of intracellular antibody The intracellular antibody content of the cells was quantified using flow cytometry as follows. $1 \times 10^{6}$ cells taken from the T-flasks were washed twice by centrifugation (5 min, $4^{\circ} \mathrm{C}, 200 \mathrm{~g}$ ) with phosphate buffered saline (PBS) and centrifuged again. After discarding the supernatant, the cell pellet was resuspended in cold ethanol and stored at $4{ }^{\circ} \mathrm{C}$ and $-20^{\circ} \mathrm{C}$, respectively. Cell samples accumulated during a batch culturc were stained and analyzed at the same time and conditions in order to avoid day-to day variation in flow cytometer measurements. We did not see any significant decrease in antibody content during storage over a month regardless of fixation temperatures used (refer to Fig. 4(A)). Elhanol-fixed cells were washed twice by centrifugation with PBS. Cells wcre resuspended in $0.4 \mathrm{ml}$ of a 1:30 dilution of fluorescein-isothiocyanate (FITC)-labeled goat antimouse IgG2b (heavy chain specific, Southern Biotechnology Associates, Birmingham, $\mathrm{AL}$ ), and then incubated at $4{ }^{\circ} \mathrm{C}$ for $45 \mathrm{~min}$. After centrifugation, the cells were washed and resuspended in PBS. Prior to flow cytometric ancalysis, cell suspensions were filtered through a 40- $\mu$ m-nylon-mesh filter (Tetko Inc., Elmsford, NY). Green fluorescence was monitored in a Coulter EPICS 751 flow cytometer (Coulter Corporation, Hialeah, FL). The flow cytometer was calibrated with microspheres of four varying fluorescence intensities (EPICS intensity standard kit for calibration of fluorescence intensity, Coulter Corporation) prior to running samples each day. Gates were set on forward angle light scatter (FALS) and $90^{\circ}$ light scatter plots to eliminate any fluorescence from cell debris. A logarithmic amplifier was used to accumulate green fluorescence data with a large dynamic range.

Analytical methods Cell growth was monitored by counting viable cells with a hemocytometer. Viable cells were distinguished from dead cells by trypan dye exclusion method. The cell culture suspension was 
centrifuged. The supernatant was aliquoted and kept frozen at $-80^{\circ} \mathrm{C}$. The total secreted antibody, $\operatorname{IgG}_{2 \mathrm{~b}}$ was quantified using an enzyme linked immunosorbent assay (ELISA) as described previously (Lee $e t$ al., 1989). The specific antibody production rate were evaluated using an integral method as described by Renard et al., 1988.
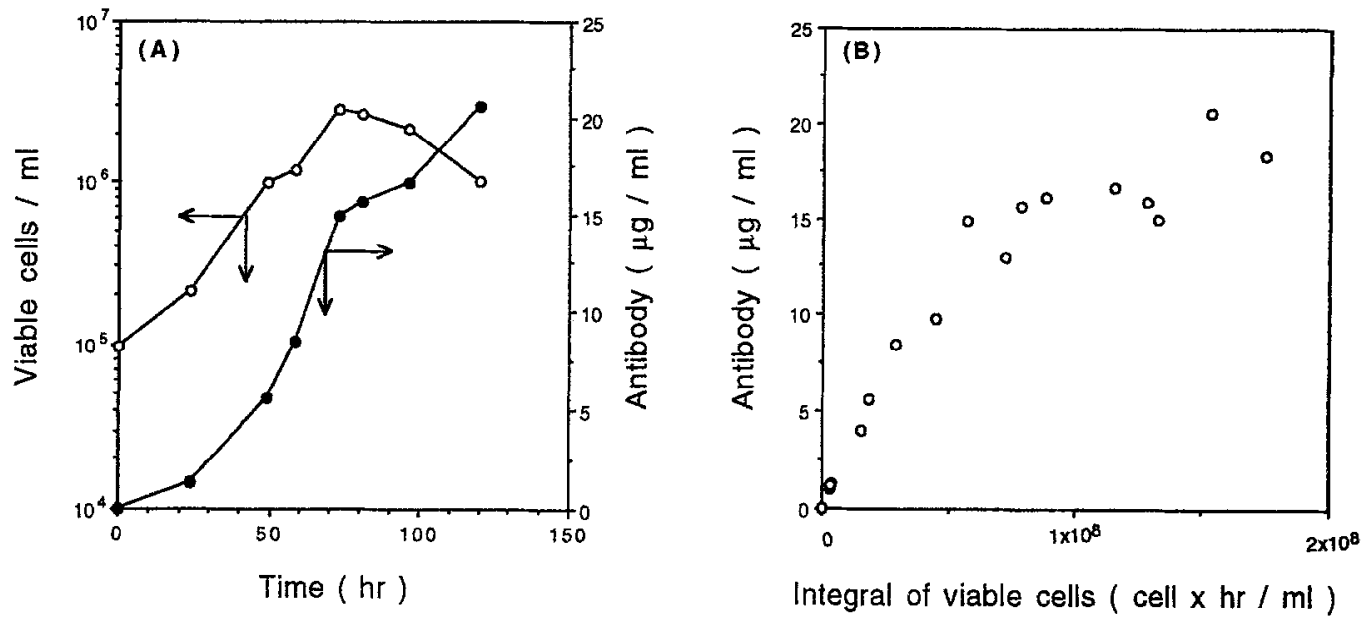

Figure 1. Batch cultivation of $\$ 3 \mathrm{H} 5 / \gamma 2 \mathrm{bA} 2$ hybridoma (A) Growth and antibody production. (B) Antibody versus integral of viable cells with respect to cultivation time.

\section{RESULTS AND DISCUSSION}

In order to study the effect of fixation temperature on the flow cytometric measurement of intracellular antibody during batch culture, we first cultivated $\mathrm{S3H} 5 / 2 \mathrm{2bA} 2$ hybridoma in T-flasks. The cell growth and secreted antibody in the medium are shown in Fig.1(A). The cell viability remained at over $90 \%$ during exponential growth but significantly dropped during decline phase of growth. The cells in the decline phase continued to secrete antibody. In order to calculate specific antibody productivity, antibody concentration versus integral of viable cells with respect to culture time is plotted in Fig. $1(\mathrm{~B})$ as described by Renard et al. (1988). Constant specific antibody productivity was not observed throughout the batch culture. The specific antibody productivity, which is calculated from the slope of curve in Fig. 1(B), was approximately $0.19 \mathrm{pg} / \mathrm{cell} / \mathrm{hr}$ until the cell concentration reached a maximum and thereafter, significantly dropped to $0.04 \mathrm{pg} / \mathrm{cell} / \mathrm{hr}$. Although there are some exceptions (Ozturk and Palsson, 1990), many hybridoma cell lines during batch culture have been reported to produce MAb at slower rates after the time integral of viable cells reached $1 \times 10^{8} \mathrm{cell} / \mathrm{ml}$ (Savinell et al., 1989).

When the intracellular $\mathrm{IgG}_{2 \mathrm{~b}}$ content is quantified using flow cytometry, FITC-conjugated goat antimouse $\operatorname{Ig} G_{2 b}$ is employed to give fluorescence by specifically labelling the heavy chain of $\operatorname{IgG}_{2} \mathrm{~b}$. Thus, the fluorescence intensity indicates the content of intracellular antibody. However, FITC-conjugated goat antimouse $\mathrm{IgG}_{2} \mathrm{~b}$ also binds nonspecifically. This nonspecific binding of FITC-conjugated goat antimouse $\mathrm{IgG}_{2} \mathrm{~b}$, which also causes fluorescence, necessitates the proper negative control to evaluate intracellular antibody accurately. Membrane composition and intracellular property of the cell may change during a batch culture resulting in variations of nonspecific binding of FITC-conjugated goat antimouse $\mathrm{IgG}_{2 \mathrm{~b}}$. In addition, fixation temperature may also influence the nonspecific binding. Thus, we cultivated S3H5/NP hybridoma to monitor the changes of nonspecific binding during batch culture. The growth of 
S3H5/NP hybridoma, which was similar to that of $\mathrm{S} 3 \mathrm{H} 5 / \gamma 2 \mathrm{bA} 2$ hybridoma is shown in Fig. 2(A). No antibody was detected in a cell culture solution and \$3H5/NP hybridoma did not have mRNA for heavy chain of IgG2b (Chuck et al., 1992). The changes in intracellular antibody content of S3H5/NP hybridoma during a batch culture which were measured by flow cytometry are shown in Fig. 2(B). The cells sampled during a batch culture were fixed at both 4 and $-20^{\circ} \mathrm{C}$. Fluorescence intensity of S3H5/NP hybridoma was almost constant during a batch culture regardless of fixation temperature used, indicating that both possible changes of the cells and fixation temperature do not influence the degree of nonspecific binding of FITCconjugated goat antimouse $\mathrm{IgG}_{2 \mathrm{~b}}$. Accordingly, the changes in fluorescence of $53 \mathrm{H} 5 / \gamma 2 \mathrm{bA} 2$ hybridoma directly reflect the changes in the intracellular antibody of the cells.
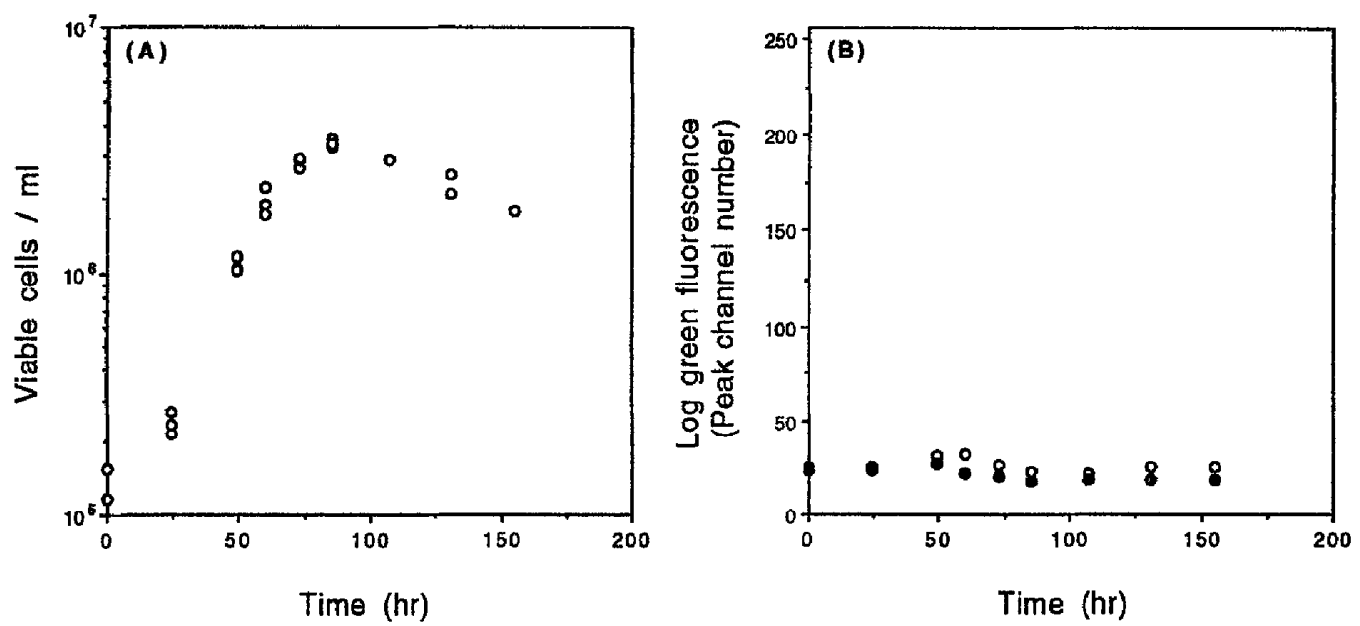

Figure 2. Batch cultivation of $\mathrm{S} 3 \mathrm{H} 5 / \mathrm{NP}$ hybridoma (A) Cell growth. (B) Fluorescence intensity of the cells fixed at $4^{\circ} \mathrm{C}$ $(-0-)$ and $-20^{\circ} \mathrm{C}(--)$, respectively.

The changes in intracellular antibody contents of $\mathrm{S} 3 \mathrm{H} 5 / \gamma 2 \mathrm{bA} 2$ hybridoma during the batch culture are shown in Fig. 3. The intracellular antibody contents of $\$ 3 \mathrm{H} 5 / 2 \mathrm{bA} 2$ hybridoma was almost constant until the cell concentration reached the maximum, and thereafter, significantly dropped. Similar observations on the changes in intracellular antibody content during a batch culture were made by other investigators using different cell lines (Meilhoc et al., 1989; AlRubeai et al., 1991). Since the changes in specific antibody production rate of $S 3 \mathrm{H} 5 / \gamma 2 \mathrm{bA} 2$

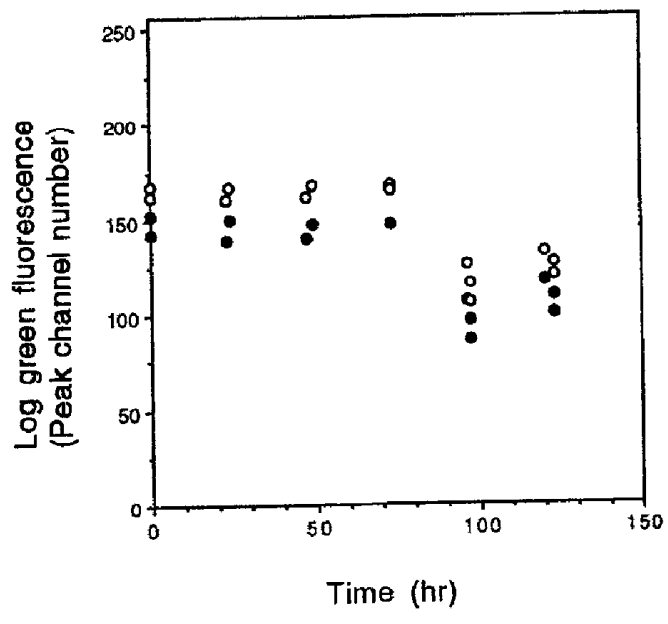
hybridoma during a batch culture are similar to those in the intracellular antibody content (refer to Fig. 1(B)), it appears that there is a good correlation between specific antibody production rate and intracellular antibody content in this case.

Figure 3. Changes in intracellular antibody contents of $S 3 \mathrm{H} 5 / / 2 \mathrm{bA} 2$ hybridoma during a batch culture shown in Fig. 1(A): - $\bullet$ - cells fixed at $4^{\circ} \mathrm{C}, \quad-0$ - cells fixed at $-20^{\circ} \mathrm{C}$. 

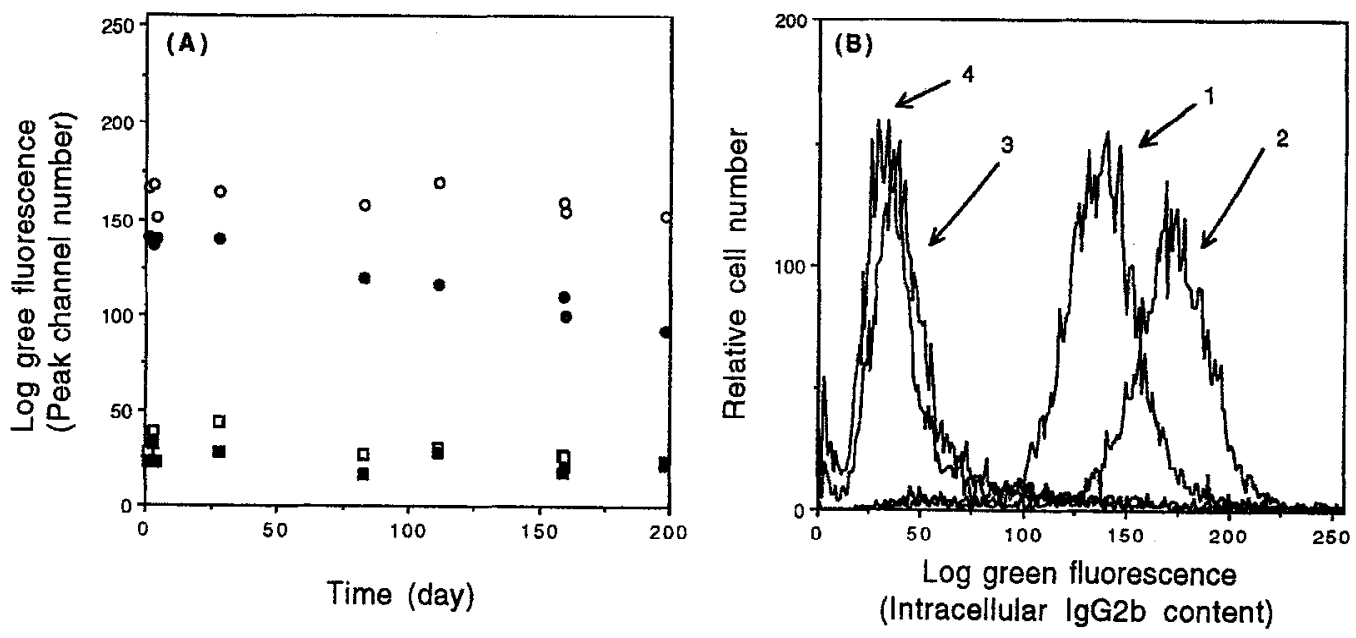

Figure 4. (A) Storage stability of intracellular antibody contents of the cells in the late exponential phase of growth at 4 and $-20^{\circ} \mathrm{C}:-\mathrm{S} 3 \mathrm{H} 5 / \gamma 2 \mathrm{bA} 2$ hybridoma fixed and stored at $4^{\circ} \mathrm{C},-\mathrm{a}-\mathrm{S} 3 \mathrm{H} 5 / \gamma 2 \mathrm{bA} 2$ hybridoma fixed and stored at $-20^{\circ} \mathrm{C}$; S3H5/NP hybridoma fixed and stored at $4^{\circ} \mathrm{C}$, $\$ 33 \mathrm{H} 5 / \mathrm{NP}$ hybridoma fixed and stored at $-20^{\circ} \mathrm{C}$. (B) Histogram of the fixed cells after 3 day of storage: Histogram 1 and 2 represent $\mathrm{S} 3 \mathrm{H} 5 / \gamma 2 \mathrm{bA} 2$ hybridoma fixed at $4^{\circ} \mathrm{C}$ and $-20^{\circ} \mathrm{C}$, respectively. Histogram 3 and 4 represent $S 3 H 5 / \mathrm{NP}$ hybridoma fixed at $4^{\circ} \mathrm{C}$ and $-20^{\circ} \mathrm{C}$, respectively.

However, since the intracellular antibody content also depends on net synthesis of antibody and dilution of intracellular antibody by cell growth (Meilhoc et al., 1989), it does not always correlate the specific antibody productivity (Lee et al., 1991). The fixation temperature did not influence the pattern of changes in intracellular antibody content of $\mathrm{S} 3 \mathrm{H} 5 / \gamma 2 \mathrm{bA} 2$ hybridoma, indicated by the fluorescence intensity, during a batch culture. However, it did influence the fluorescence intensity of $\mathrm{S} 3 \mathrm{H} 5 / 22 \mathrm{bA} 2$ hybridoma. The cells fixed at $-20^{\circ} \mathrm{C}$ showed higher fluorescence intensity than those fixed at $4{ }^{\circ} \mathrm{C}$. Accordingly, in order to preserve intracellular antibody, it is desirable to fix the cells at $-20^{\circ} \mathrm{C}$ rather than $4{ }^{\circ} \mathrm{C}$. During the fixation process, the intracellular antibody may denature faster and/or leak more out of the cells at $4{ }^{\circ} \mathrm{C}$ than at $-20^{\circ} \mathrm{C}$.

In order to examine the storage stability of the intracellular antibody of the fixed cells, the cells fixed at $4{ }^{\circ} \mathrm{C}$ and $-20^{\circ} \mathrm{C}$ were stored at $4{ }^{\circ} \mathrm{C}$ and $-20^{\circ} \mathrm{C}$, respectively. Fluorescence intensity , i.e. intracellular antibody content, vs storage time is plotted in Fig. 4(A). As shown in Fig. 4(A), fluorescence intensity of S3H5/NP hybridomas caused by nonspccific binding was constant during a storage period of over 6 months regardless of storage temperature. This result indicates that the changes in fluorescence of $\mathrm{S} 3 \mathrm{H} 5 / \gamma 2 \mathrm{bA} 2$ hybridoma directly retlect the changes in the intracellular antibody of the cells. The intracellular antibody content of $\$ 3 \mathrm{H} 5 / \gamma 2 \mathrm{bA} 2$ hybridoma stored at $4{ }^{\circ} \mathrm{C}$ decreased slowly during a storage period while that of the cells stored at $-20^{\circ} \mathrm{C}$ did not decrease noticeably during a storage period of over 6 months. Accordingly, storage stability of intracellular antibody at $-20^{\circ} \mathrm{C}$ was better than that at $4{ }^{\circ} \mathrm{C}$. Figure 4(B) shows typical histograms of $\$ 3 \mathrm{H} 5 /$ /2bA2 and $\$ 33 \mathrm{H} / \mathrm{NP}$ hybridomas which were fixed at both $4{ }^{\circ} \mathrm{C}$ and $-20^{\circ} \mathrm{C}$.

In conclusion, by monitoring the changes in intracellular antibody content of $53 \mathrm{H} 5 / 22 \mathrm{bA} 2$ hybridoma during a batch culture using flow cytometry, it is more desirable to fix and store the cells at $-20^{\circ} \mathrm{C}$ than $4^{\circ} \mathrm{C}$ with regard to preservation of intracellular antibody and storage stability. 
Acknowledgments The authors thank Dr. Mark Kaminski for supplying the cell line. The authors also thank Mehran Shahabi for his help in flow cytometry. This work was supported by National Science Foundation (BSC-9009389) and KAIST.

\section{REFERENCES}

Al-Rubeai M., Emery A. N., and Chalder S. (1991). J. Biotechnol. 19, 67-82.

Altshuler G. L., Dilwith R., Sowek J., and Belfort G. (1986). Biotechnol. Bioeng. Symp. 17, 725-736.

Bergman Y., Haimovich J. (1977). Eur. J. Immunol. 7, 413-417.

Chuck A. S., and Palsson B. O. (1992). Biotechnol. Bioeng. 39, 354-360.

Chuck A. S., Merritt S. E., and Palsson B. O. (1992). “Population dynamics of non-producing and producing hybridomas in serum-free medium" Presented at AIChE annual meeting. Miami Beach, Florida.

Clevenger C. V., Bauer K.D., and Epstein A. L. (1985). Cytometry 6, 208-214.

Dalili M., and Ollis D. F. (1990). Biotechnol. Bioeng. 36, 64-73.

Heath C., Dilwith R., and Belfort G. (1990). J. Biotechnol. 15, 71-90.

Jacobberger J. W., Fogleman D., and Lehman J.M. (1986). Cytometry 7, 356-364.

Lee G. M., Huard T. K., and Palsson B. O. (1989). Hybridoma 8, 369-375.

Lee G. M., and Palsson B. O. (1990). Biotechnol. Bioeng. 36, 1049-1055.

Lee G. M., Varma A., and Palsson B. O. (1991). Biotechnol. Bioeng. 38, 821-830.

Levitt D., and King M. (1987). J. Immunol. Methods 96, 233-237.

McKinney K. L., Dilwith R., and Belfort G. (1991). Biotechnol. Prog. 7, 445-454.

Meilhoc E., Wittrup K. D., and Bailey J. E. (1989). J. Immunol. Methods 121:167-174.

Ozturk S. S., and Palsson B. O. (1990). J. Biotechnol. 16, 259-278.

Ozturk S. S., and Palsson B. O. (1990). Hybridoma 9, 167-175.

Reddy S., Bauer K. D., and Miller W. M. (1992). Biotechnol. Bioeng. 40, 947-964.

Renard J. M., Spagnoli R., Mazier C., Salles M. F., and Mandine E. (1988). Biotechnol. Lett. 10, 91-96.

Savinell J. M., Lee G. M., and Palsson B. O. (1989). Bioprocess Engr. 4, 231-234.

Sen S., Hu W. S., and Srienc, F. (1990). Enzyme Microb. Technol. 12, 571-576.

Shapiro H. M. (1988). Practical Flow Cytometry. New York: Alan R. Liss.

Van Ewijk W., Van Soest P. L., Verkerk A., and Jongkind J. F. (1984). Histochem. J . 16, 179-193.

Watson, J. V. (1991). Introduction to Flow Cytometry. Cambridge: Cambridge University Press. 